\title{
A Comparative Study of the Adjustment among Secondary and Senior Secondary School Students of Almora District
}

\author{
Devendra Singh Chamyal ${ }^{1 *}$, Dr. Bheema Manral $^{2}$
}

\section{ABSTRACT}

The present investigation compares the adjustment of secondary and senior secondary school Students in Almora district. Population contain all secondary and senior secondary school students of Almora district. 220 students were selected randomly from secondary schools of Almora district which contain both male and female students. Survey method was used to the present research. For this purpose of investigation “Adjustment Inventory” by A.K.P. Sinha and R.P. Singh was used. Adjustment inventory were distributed to 220 secondary school students (both male and female). Descriptive statistics were used. Means, standard deviation, values were calculated. t-test was used to find the significance of difference in adjustment among secondary school students and senior secondary school students at $\mathrm{p}<0.01$ and $\mathrm{p}<0.05$. The number of students who participated in the study were 220 including $45.46 \%$ females and $54.55 \%$ males. For the purpose of discussion and comparison participants were selected from twelve different categories such as boys (54.55\%), girls (45.46\%),science students ( $47.706 \%$ ), art students (52.30\%), secondary school students (50\%), senior secondary school students (50\%), upper caste (52.27\%), lower caste (47.72\%), government school students (53.64\%), and private school students (46.37\%). Most of them are good adjustable. The analysis revealed that knowledge of adjustment and his factor's (emotional, social and educational) may be used to identify well adjustment or maladjustment in our college, home and social environment. Comparison may profitably be used for this purpose.

Keywords: Adjustment, Student, Secondary, School, Gender

You may have heard someone say that “somebody just doesn't adjust to situation” or “somebody facing problem in adjustment”. Adjustment is a necessary characteristic to be able to live peacefully in this world. Adjustment problem starts from the birth and continues till death,

\footnotetext{
${ }^{1}$ M.Sc. Chemistry, M.A. Mathematics, M.A. History, M.Ed., Ph.D. scholar, kumaun university Nainital, S. S. J. Campus Almora, India

${ }^{2}$ Professor, Education Department, kumaun university Nainital, S. S. J. Campus Almora, India

*Responding Author
}

Received: December 15, 2016; Revision Received: January 11, 2017; Accepted: January 27, 2017

(C) 2017 Chamyal D, Manral B; licensee IJIP. This is an Open Access Research distributed under the terms of the Creative Commons Attribution License (creativecommons.org/licenses/by/2.0), which permits unrestricted use, distribution, and reproduction in any Medium, provided the original work is properly cited. 


\section{A Comparative Study of the Adjustment among Secondary and Senior Secondary School Students of Almora District}

various situations arise at home, School, college, and workplace. Adjustment is the process of arriving at a balanced state between the need of individual and their satisfaction. Home and school play pivotal role in the adjustment of an individual. Adjustment is a popular expression used by people in day to day life. For example, while traveling in a - bus Or a train, we often hear or use this term; even when a guest comes to stay with us for a few days we have to adjust him/her in our house. Though sometimes we face problems in making these adjustments, they are important to maintain personal as well as social peace and harmony.

Adjustment in psychology, the behavioral process by which humans and other animals maintain an equilibrium among their various needs or between their needs and the obstacles of their environments. A sequence of adjustment begins when a need is felt and ends when it is satisfied. Hungry people, for example, are stimulated by their physiological state to seek food. When they eat, they reduce the stimulating condition that impelled them to activity, and they are thereby adjusted to this particular need. Though sometimes we face problems in making Emotional, Social \& Educational adjustments. They are important to maintain personal as well as social peace and harmony. The learner adjusts actively in the school environment rather than passively adjusting to the school`s program. Adjustment is essentially a process of re-learning. Although a variety of factors influence adjustments, directly or indirectly, many maladjustments are primarily the result of unfortunate learning experience. Adjustment can be viewed from two angles. Firstly, adjustment may be viewed as an achievement or how well a person handles his conflicts and overcomes the resulting tension. Secondly, adjustment may be looked upon as a process as to how a person adjusts or compromises to his conflicts. Thus adjustment maintains peace and harmony in home, school, and society and in the country. So Adjustment can be defined as a psychological process. The concept of adjustment initially was biological and it was termed as adaption.

According to the Shaffer, L.S. “Adjustment is the process by which living organism maintain a balance between his needs and the circumstances that influence the satisfactions of these needs. according to the Carter V. Good "adjustment is the process of finding and adopting modes of behaviour suitable to the environment or the change in the environment”. Adjustment can be defined as a process of altering one's behaviour to reach a harmonious relationship with their environment. This is typically a response brought about by some type of change that has taken place. The stress of this change causes one to try to reach a new type of balance or homeostasis between the individual (both inwardly and outwardly), and with their environment. According to Lazasus (1976) at the psychological level, however adjustment has come to mean the individuals struggle to survive in or her surroundings. At the present study aimed to compare adjustment among secondary and senior secondary school students in almora district. Almora district is situated in state Uttarakhand. In the present study the adjustment of secondary and senior 


\section{A Comparative Study of the Adjustment among Secondary and Senior Secondary School Students of Almora District}

secondary level girls and boys and has tried to find out the differences on the pattern of adjustment on the basis of academic stream, gender, level, region, type of school, caste.

\section{Statement of the problem:}

"A comparative study of the adjustment among secondary and senior secondary school students of Almora district".

\section{Objective of the study:}

The purpose of the present study to compare the total ( Emotional, Social and Educational) adjustment of secondary and senior secondary school students on the basis of their gender, type of school, caste, level, academic stream and living place.

\section{Delimitations of the study:}

The problem is very vast \& wide. Hence the investigator has delimited the problem as under:

1. The study were confined to Uttarakhand board students only.

2. The study were confined to secondary and senior secondary level students (class $9^{\text {th }}$ onwards-10,11,12).

3. The area of present study were of limited to Almora district and six colleges were taken for sample.

\section{METHOD}

Survey method was used to research.

\section{Population:}

Population contained all secondary and senior secondary school students of Almora district .

\section{Hypothesis:}

1. There is no significant difference in adjustment (emotional, social and educational) of secondary and senior secondary level students on the basis of their living place.

2. There is no significant difference in adjustment (emotional, social and educational) of secondary and senior secondary level students on the basis of their gender.

3. There is no significant difference in adjustment (emotional, social and educational) of secondary and senior secondary level students on the basis of their academic stream.

4. There is no significant difference in adjustment (emotional, social and educational) of secondary and senior secondary level students on the basis of their type of school.

5. There is no significant difference in adjustment (emotional, social and educational) of secondary and senior secondary level students on the basis of their caste.

6. There is no significant difference in adjustment (emotional, social and educational) of secondary and senior secondary level students on the basis of their class level. 


\section{A Comparative Study of the Adjustment among Secondary and Senior Secondary School Students of Almora District}

\section{Sample:}

The present study was carried out on secondary and senior secondary school students of Almora District. Present study contain 110 secondary and 110 senior secondary school students out of which 120 were boys and 100 were girls.

\section{Tool:}

In the present investigation measure the Adjustment “Adjustment Inventory” for secondary and senior secondary school students made by A.K.P. Sinha and R.P. Singh was used. Adjustment Inventory for school students has been designed for Hindi medium students. The inventory seeks to segregate well adjusted secondary school students (age group 14 to 18 years) from poorly adjusted in three areas of adjustment viz. Emotional, Social and Educational. The adjustment inventory consists 60 items with yes /no response pattern. 20 were Emotional, 20 Social \& 20 were Educational Adjustment items.

\section{Administration and Procedure:}

The boys and Girls who were studying in Secondary and senior Secondary School of different areas in Almora District, were randomly selected \& A.K.P. Sinha and R.P. Singh “Adjustment Inventory ${ }^{\text {ee }}$ were distributed to 110 secondary and 110 senior Secondary school students and data was collected. The students were asked to respond to each item according to the response format provided in the questionnaire. In case of multiple choice questions, students were instructed to choose only one answer from provided list of options. The secondary and senior secondary school teachers received a full explanation of how to fill in the questionnaire. The participants were encouraged to approach the investigator whenever they needed clarification for any doubt. The obtain data from 220 students (both boys and girls) were analyzed with the help of mean, SD and t-test.

\section{Statistical analysis:}

Data ware analyzed using excel programme. Descriptive statistics were used and t-value were calculated. t-test was used to find the significance of difference in study of adjustment among 110 secondary and 110 senior secondary school students at $\mathrm{p}<0.05$ and $\mathrm{p}<0.01$.

\section{RESULTS}

The number of students who participated in the study was 220 including boys (54.55 \%), girls (45.46\%) ,science students ( $47.706 \%)$, art students (52.30\%), secondary school students (50\%), senior secondary school students (50\%), upper caste $(52.27 \%)$, lower caste (47.72\%), government school students (53.64\%), and private school students (46.37\%). Most of them are average adjusted. The data regarding adjustment were analyzed as follows: 
A Comparative Study of the Adjustment among Secondary and Senior Secondary School Students of Almora District

Table no. 1 Comparative study of adjustment among secondary and senior secondary school students on the basis of their living place

\begin{tabular}{|c|c|c|c|c|c|}
\hline Category & Sample (N) & Mean (M) & $\begin{array}{c}\text { Standard } \\
\text { deviation(S.D.) }\end{array}$ & t-value & $\begin{array}{c}\text { Significance } \\
\text { Level }\end{array}$ \\
\hline Rural & 162 & 6.78 & 4.95 & \multirow{2}{*}{2.46} & $\begin{array}{c}\text { Significant at } \\
0.05\end{array}$ \\
\hline Urban & 58 & 5.54 & 2.21 & & \\
\cline { 1 - 3 }
\end{tabular}

$\mathrm{Df}=218$, t-value is significant at 0.05 level

The above result table No.1 we can see that there was significant difference in adjustment (emotional, social and educational) among secondary and senior secondary school students of rural and urban areas at significance level 0.05. t-value indicates that urban students have better adjustment than rural students. Thus the null hypothesis, I which states "There is no significant difference in adjustment (emotional, social and educational) of secondary and senior secondary level students on the basis of their living place" was rejected. The main reason of this difference may be urban students have more facilities for education and they face problems by situations while in the rural areas students have less opportunity for education and other curriculum activities. Hence urban students were of higher adjusted than rural students.

Table no. 2 Comparative study of adjustment among secondary and senior secondary school students on the basis of their gender

\begin{tabular}{|c|c|c|c|c|l|}
\hline Category & Sample (N) & Mean (M) & $\begin{array}{c}\text { Standard } \\
\text { deviation(S.D.) }\end{array}$ & t-value & $\begin{array}{l}\text { Significance } \\
\text { level }\end{array}$ \\
\hline Girls & 100 & 6.53 & 3.24 & \multirow{2}{*}{$\begin{array}{c}\text { non-significant } \\
\text { at } 0.05\end{array}$} \\
\hline Boys & 120 & 7.04 & 8.58 & .50 & \\
\hline
\end{tabular}

$\mathrm{Df}=218$, t-value is non-significant at 0.05 level

The above result table No.2 we can see that there was non-significant difference in adjustment (emotional, social and educational) among secondary and senior secondary school students of girls and boys at significance level 0.05. t-value indicates that boys and girls have same adjustment. Thus the null hypothesis, I which states "There is no significant difference in adjustment (emotional, social and educational) of secondary and senior secondary level students on the basis of their gender" was accepted. The main reason of this may be nowadays girls and boys are similarly participated in all field of education and life as co-curricular activities, tuitions, games, etc. So both girls and boys have same opportunity to Learn adjusting qualities. 
A Comparative Study of the Adjustment among Secondary and Senior Secondary School Students of Almora District

Table no. 3 Comparative study of adjustment among secondary and senior secondary school students on the basis of their academic stream

\begin{tabular}{|c|c|c|c|c|c|}
\hline Category & Sample (N) & Mean (M) & $\begin{array}{c}\text { Standard } \\
\text { deviation(S.D.) }\end{array}$ & t-value & $\begin{array}{c}\text { Significance } \\
\text { Level }\end{array}$ \\
\hline Art & 57 & 6.25 & 3.29 & & $\begin{array}{c}\text { non- significant } \\
\text { at } 0.05\end{array}$ \\
\hline Science & 52 & 6.99 & 6.21 & .45 & \multicolumn{2}{|c|}{} \\
\hline
\end{tabular}

$\mathrm{Df}=107$, t-value is non-significant at 0.05 level

The above result table No.3 we can see that there was non-significant difference in adjustment (emotional, social and educational) among secondary and senior secondary school students of art stream and science stream at significance level 0.05. t-value indicates that art stream and science stream students have same adjustment. Thus the null hypothesis, I which states "There is no significant difference in adjustment (emotional, social and educational) of secondary and senior secondary level students on the basis of their academic stream" was accepted. The main reason of this difference may be that both stream students have same opportunity to learn anything in families, school, societies etc.

Table no. 4 Comparative study of adjustment among secondary and senior secondary school students on the basis of their type of school

\begin{tabular}{|l|c|c|c|c|c|}
\hline \multicolumn{1}{|c|}{ Category } & Sample (N) & Mean (M) & $\begin{array}{c}\text { Standard } \\
\text { deviation(S.D.) }\end{array}$ & t-value & $\begin{array}{c}\text { Significance } \\
\text { Level }\end{array}$ \\
\hline Government & 118 & 7.55 & 5.53 & \multirow{2}{*}{2.11} & $\begin{array}{c}\text { Significant } \\
\text { at } 0.05\end{array}$ \\
\hline Private & 102 & 5.37 & 2.73 & & \\
\hline
\end{tabular}

$\mathrm{Df}=218$, t-value is significant at 0.05 level

The above result table No.4 we can see that there was significant difference in adjustment (emotional, social and educational) among secondary and senior secondary school students of government and private schools at significance level 0.05. t-value indicates that private school students have better adjustment than government schools students. Thus the null hypothesis, I which states "There is no significant difference in adjustment (emotional, social and educational) of secondary and senior secondary level students on the basis of their type of school” was rejected. The main reason of this difference may be that private schools attending his mind on students discipline, living skill, adjustment in societies and teacher staff are full. 
A Comparative Study of the Adjustment among Secondary and Senior Secondary School Students of Almora District

Table no. 5 Comparative study of adjustment among secondary and senior secondary school students on the basis of their caste

\begin{tabular}{|c|c|c|c|c|c|}
\hline Category & Sample (N) & Mean (M) & $\begin{array}{c}\text { Standard } \\
\text { deviation(S.D.) }\end{array}$ & t-value & $\begin{array}{c}\text { Significance } \\
\text { level }\end{array}$ \\
\hline Upper caste & 115 & 7.27 & 5.26 & & Significant \\
Lower caste & 105 & 5.55 & 2.80 & 3.07 & at 0.01 \\
\hline
\end{tabular}

$\mathrm{Df}=218$, t-value is significant at 0.01 level

The above result table No.5 we can see that there was significant difference in adjustment (emotional, social and educational) among secondary and senior secondary school students of upper caste and lower caste at significance level 0.01. t-value indicates that lower caste students have better adjustment than upper caste students. Thus the null hypothesis, I which states "There is no significant difference in adjustment (emotional, social and educational) of secondary and senior secondary level students on the basis of their caste" was rejected. The main reason of this difference may be that upper caste students growing up very fast and they participated in all subject or activities. Nowadays there is no differences between upper caste and lower caste in societies.

Table no. 6 Comparative study of adjustment among secondary and senior secondary school students on the basis of their class level

\begin{tabular}{|c|c|c|c|c|l|}
\hline Category & Sample(N) & Mean (M) & $\begin{array}{c}\text { Standard } \\
\text { deviation(S.D.) }\end{array}$ & $\begin{array}{c}\text { t- } \\
\text { value }\end{array}$ & $\begin{array}{c}\text { Significance } \\
\text { level }\end{array}$ \\
\hline Secondary & 110 & 6.34 & 4.18 & \multirow{2}{*}{.53} & $\begin{array}{l}\text { Non -significant } \\
\text { at } 0.05\end{array}$ \\
\hline $\begin{array}{c}\text { Senior } \\
\text { secondary }\end{array}$ & 110 & 6.66 & 4.85 & .53 \\
\hline
\end{tabular}

$\mathrm{Df}=218$, t-value is non-significant at 0.05 level

The above result table No.6 we can see that there was non-significant difference in adjustment (emotional, social and educational) among secondary and senior secondary school students at significance level 0.05 . t-value indicates that secondary school students and senior secondary school students have same adjustment. Thus the null hypothesis, I which states "There is no significant difference in adjustment (emotional, social and educational) of secondary and senior secondary level students on the basis of their level" was accepted. The main reason of this difference may be secondary and senior secondary school students are of about same age group as adolescent and same thinking level. 


\section{A Comparative Study of the Adjustment among Secondary and Senior Secondary School Students of Almora District}

\section{DISCUSSION}

In the present study, almost of the students were of good adjustment.(mean $=5$ to 8) urban living students were better adjustable position than rural living students. Girls and boys were of same adjusted in total adjustment. Art stream students and science stream students were of same adjustment. Private school students were of better adjustable than government school students. Lower caste students were of better adjustable than upper caste students. Secondary school and senior secondary school students were of same adjustment. When the Mean scores for males, females, rural, urban, upper caste, lower caste, government school, private school, secondary, senior secondary, science and Art stream students were compared, it was observed that there existed a significant difference between the students of three branches(Emotional, Social \& Educational) in terms of adjustment. The observed differences in the adjustment between males, females, rural, urban, upper caste, lower caste, government school, private school, secondary, senior secondary, science and Art stream students were partly due to differences in the living areas, societies, subject interest and partly due to the availability of resources. Above calculations shows that government school students were of least adjusted and private school students were of highest adjusted.

\section{CONCLUSION}

We can conclude by data analysis as follows:

1. There is significant difference in adjustment of secondary and senior secondary school students in relation to their living place.

2. There is no significant difference in adjustment of secondary and senior secondary school students in relation to their gender

3. There is no significant difference in adjustment of secondary and senior secondary school students in relation to their academic stream.

4. There is significant difference in adjustment of secondary and senior secondary school students in relation to their type of school.

5. There is significant difference in adjustment of secondary and senior secondary school students in relation to their caste.

6. There is no significant mean difference in emotional adjustment of secondary school students in relation to their class level.

\section{Acknowledgments}

The author appreciates all those who participated in the study and helped to facilitate the research process.

\section{Conflict of Interests}

The author declared no conflict of interests. 
A Comparative Study of the Adjustment among Secondary and Senior Secondary School Students of Almora District

\section{REFERENCES}

Best, J.W.and J.V. kahn (2014).Research in education. Delhi: PHI learning private limited

Gururani, R.(2013). "A study of the adjustment of senior secondary school students of Haldwani city.”Unpublished Dissertation, Department of education, K.U. Nainital.

Koul, L.(2010). Methodology of educational research. Noida: Vikas publishing house.

Makwana, M. D. And Kaji,S. M.(2014) "Adjustment of Secondary School Students in Relation to their Gender” The International Journal of Indian Psychology, Gujarat: India, Volume 2, Issue 1, Skinner, C.E.(1977). Educational psychology. New Delhi: Printed hall.

How to cite this article: Chamyal D, Manral B (2017), A Comparative Study of the Adjustment among Secondary and Senior Secondary School Students of Almora District, International Journal of Indian Psychology, Volume 4, Issue 2, No. 85, ISSN:2348-5396 (e), ISSN:2349-3429 (p), DIP:18.01.009/20170402, ISBN: 978-1-365-68608-5 